\title{
Social factors related to the clinical severity of influenza cases in Spain during the A (H1N1) 2009 virus pandemic
}

\author{
José María Mayoral ${ }^{1,17^{*}}$, Jordi Alonso ${ }^{2,3}$, Olatz Garín ${ }^{2,3}$, Zaida Herrador ${ }^{4}$, Jenaro Astray ${ }^{5}$, Maretva Baricot ${ }^{3}$, \\ Jesús Castilla ${ }^{3,6}$, Rafael Cantón ${ }^{3,7}$, Ady Castro ${ }^{8}$, Miguel Delgado-Rodríguez ${ }^{3,9}$, Alicia Ferri ${ }^{3}$, Pere Godoy 3,10, \\ Fernando Gónzález-Candelas 3,11, Vicente Martín ${ }^{3,12}$, Tomás Pumarola ${ }^{13}$, José María Quintana ${ }^{3,14}$, Núria Soldevila ${ }^{3}$, \\ Sonia Tamames ${ }^{15}$, Ángela Domínguez ${ }^{3,16}$ and the CIBERESP Cases and Controls in Pandemic Influenza Working \\ Group, Spain
}

\begin{abstract}
Background: During the 2009 influenza pandemic, a change in the type of patients most often affected by influenza was observed. The objective of this study was to assess the role of individual and social determinants in hospitalizations due to influenza A (H1N1) 2009 infection.

Methods: We studied hospitalized patients (cases) and outpatients (controls) with confirmed influenza A (H1N1) 2009 infection. A standardized questionnaire was used to collect data. Variables that might be related to the hospitalization of influenza cases were compared by estimation of the odds ratio (OR) and 95\% confidence intervals $(\mathrm{Cl})$ and the variables entered into binomial logistic regression models.

Results: Hospitalization due to pandemic A (H1N1) 2009 influenza virus infections was associated with non-Caucasian ethnicity (OR: 2.18, 95\% Cl 1.17-4.08), overcrowding (OR: 2.84, 95\% Cl 1.20-6.72), comorbidity and the lack of previous preventive information (OR: $2.69,95 \% \mathrm{Cl}: 1.50-4.83$ ). Secondary or higher education was associated with a lower risk of hospitalization (OR 0.56, $95 \% \mathrm{Cl}: 0.36-0.87$ )

Conclusions: In addition to individual factors such as comorbidity, other factors such as educational level, ethnicity or overcrowding were associated with hospitalization due to A (H1N1) 2009 influenza virus infections.
\end{abstract}

Keywords: Influenza A (H1N1) 2009, Pandemic, Hospitalization, Social factors

\section{Background}

The pathogenesis of infectious diseases is generally well known. Biomedical advances have resulted in a wide understanding of the most common infectious agents. However, individual and social factors also affect the morbidity and mortality of infectious diseases and may not be as easy to identify, measure or modify. These factors also seem to contribute to the differences in disease incidence, evolution and severity detected between individuals and population groups [1-7].

\footnotetext{
* Correspondence: josem.mayoral.sspa@juntadeandalucia.es

${ }^{1}$ Servicio de Vigilancia epidemiológica de Andalucia, Sevilla, Spain

${ }^{17}$ So de Epidemiología. Consejería de Salud. Andalucía, Avda. de la Innovación s/n, 41080, Sevilla, Spain

Full list of author information is available at the end of the article
}

Objective material conditions and available individual and social resources influence the health status, regardless of the health problems presented $[8,9]$. This relationship has been widely studied, especially in the context of chronic disease. However, applying this approach to acute infectious diseases may be more difficult, for reasons which include the short period of disease incubation and duration and accessible, efficacious treatments [10,11].

After the A (H1N1) 2009 influenza virus pandemic, some studies have analyzed the role of specific clinical variables as risk factors for the development of severe influenza. However, studies on the 1918 pandemic point to overcrowding and hunger as the main causes of the rapid expansion of cases throughout Europe [12]. Although individual factors such as nutrition, and the

\section{Ciomed Central}


socioeconomic or educational level are less-frequently considered when studying influenza, there is sufficient evidence of their impact on health and disease evolution to warrant study of their possible role in severe cases of influenza [13-16].

This is especially relevant in the case of A (H1N1) 2009 influenza virus infections, given the profile of severe cases reported during the pandemic. A major epidemiological difference between pandemic influenza virus A (H1N1) 2009 infections and previous seasonal influenza infections was that the greatest proportion of severe cases occurred in young people and young adults, resulting in an increase in the potential life years lost [17-22]. However, the virulence of the disease was particularly high among people aged $\geq 65$ years: while the incidence in the community was low in this age group, the proportion of severe, hospitalized cases was higher. In Spain, it is estimated that 2.5\% of all cases of influenza attended by primary care centres were in people aged $\geq 65$ years, compared with $10.6 \%$ admitted to hospital intensive care units [23].

Other determinants, such as differences in access to preventive pharmacological and non-pharmacological measures have also been show to play a role in infections of acute onset [16,24]. Study of access to and the use of health services may be valuable not only with respect to the clinical evolution of cases but also in determining how well they function in an atypical situation such as the 2009 pandemic [25-28]. Few studies of severe cases of influenza have included non-clinical factors even though it is known that vulnerability to infectious diseases is mediated by individual and social conditions and that these are a European public health priority [1,29]. The aim of this study was to analyze individual and social factors associated with hospitalization during the influenza A (H1N1) 2009 pandemic.

\section{Methods \\ Study design}

We performed a multicenter matched case-control study. Patients were recruited from hospitals and primary healthcare clinics and emergency units in seven Spanish regions (Andalusia, Catalonia, Castile and Leon, Madrid, Navarre, Basque Country and Valencia Community) between July 2009 and February 2010, during the peak of the influenza A (H1N1) 2009 pandemic in Spain [24].

The sample size required to detect a relative risk (OR) of 1.5 assuming a prevalence of the investigated factors in outpatients of 0.15 , a bilateral level of significance of $\alpha=0.05$ and a power of $\beta=0.80$ was 654 , using the criteria proposed by Schlesselman [30].

Selection of cases and controls:

Hospitalized cases were defined as all patients admitted during the study period due to influenza-like illness, respiratory infection (including pneumonia), septic shock or multiple organ failure in whom pandemic influenza virus A (H1N1) 2009 infection was confirmed. Nosocomial cases were excluded.

For each hospitalized case, one control was identified among patients attended by primary health care clinics and emergency units due to influenza-like illness or respiratory infection in whom A (H1N1) 2009 infection was confirmed using the same diagnostic techniques as for cases. Controls were matched with cases according to age ( \pm 6 months in patients aged $0-2$ years; \pm 3 years in patients aged 3-17 years and \pm 5 years in patients aged $>$ 17 years), date of hospitalization of the case ( \pm 21 days) and province of residence of the case. If there was more than one exact match, the control selected was the first patient attended in an outpatient centre from the same province as the hospitalized case whose sample was laboratory confirmed.

Exclusion criteria for cases and controls were failure to answer the questionnaire and refusal of informed consent.

Influenza virus A (H1N1) 2009 infection was confirmed in cases and controls by real time RT-PCR. After giving informed consent to participate in the study, cases and controls were administered a structured questionnaire by specifically-trained health professionals in order to collect sociodemographic and medical information on unfavourable medical factors (smoking, morbid obesity [body mass index $(\mathrm{BMI}) \geq 40]$, hypertension, lung disease, cardiovascular disease, kidney failure, diabetes, chronic liver disease, immunodeficiency, disabling neurological disease, malignancy, transplantation, cognitive dysfunction, seizure disorders and rheumatic diseases) and information on preventive measures received through various means (health centres, the media, internet, etc.) during the previous year on preventing the spread of influenza and antecedent of influenza pandemic vaccination. The social variables of interest in this study were the educational level, overcrowding (below the fifth percentile of the distribution of square metres available per person in the normal residence of all study participants), ethnicity and the use of outpatient healthcare services, family physicians or non-hospital emergency units due to influenza symptoms in the 7 days before hospital admission in cases and a medical visit due to influenza symptoms in controls.

Cases and controls were offered the possibility of completing the survey in person at a health centre or by telephone.

The median time from hospitalization of cases or taking the sample from outpatient controls until the survey was calculated.

\section{Statistical analysis}

A descriptive analysis was made of the characteristics of cases and controls. A bivariate analysis was made using 
McNemar's $\chi 2$ test for matched categorical variables. A multivariate analysis was performed using binomial logistic regression which included all variables of interest and possible confounding factors. Associations were measured using crude and adjusted odds ratios (OR) and their 95\% confidence intervals (CI).

The multivariate models were calculated using Cox conditional logistic regression models.

Variables were selected manually and entered in an initial model that included all selected variables. Variables of interest and significant variables in the bivariate analysis were entered in the model. The probability of the steps for entry was 0.05 and the output 0.10 . The cutoff point for iteration was 0.5 and the maximum number of iterations was 20. To assess whether this was an appropriate model, the Wald statistic was calculated. The criterion for selecting a new model was determined by the coefficient of likelihood of the model. The analysis was made using the SPSS v13.0 statistical package.

The variable age was included as a continuous variable in order to adjust the multivariate model.

\section{Data confidentiality and ethical considerations}

All information collected was treated as confidential according to the law on observational studies. The study was approved by the Ethics Committee of the hospitals involved (Clinical Research Ethics Committee, Hospital Costa del Sol; Autonomous Clinical Trials Committee of Andalusia; Clinical Research Ethics Committee, Clinica de Leon; Clinical Research Ethics Committee, Municipal Institute of Healthcare (CEIC-IMAS); Clinical Research Ethics Committee, Corporación Sanitaria ParcTaulí of Sabadell; Research Committee, Sant Joan de Déu University Hospital; Clinical Research Ethics Committee, Basque Country; Clinical Research Ethics Committee, Doctor Peset Univeristy Hospital, Valencia; and, Clinical Research Ethics Committee, Clinical Research Ethics Committee, General Directorate of Public Health, Valencia.

Information was collected after written informed consent was obtained from all patients.

\section{Results}

A total of 704 possible eligible hospitalized cases and 716 possible eligible controls were considered for the study. Five hospitalized cases and eleven controls were excluded because they did not give consent to participate and 6 possible eligible controls were excluded because failure to response the questionnaire. So, finally a total of 699 cases and 699 controls met the inclusion criteria and were included in the analysis. Baseline characteristics of cases and controls are shown in Table 1.

The median time from hospitalization of cases or taking the sample from outpatient controls until the survey was
99 days (range 0 to 404) for hospitalized cases and 155 days (range 0 to 414) for outpatient controls.

No significant differences were found between sexes in the proportion of hospitalized cases. A total of $87.1 \%$ of cases and $94.1 \%$ of controls were Caucasian, $2.2 \%$ of cases and $0.3 \%$ of controls were Roma ( $\mathrm{p}=0.002), 6.8 \%$ of cases and $2.4 \%$ of controls were Amerindian ( $\mathrm{p}<0.001$ ) and $2.5 \%$ of cases and $0.9 \%$ of controls were Arab or North African ( $<<0.05)$.

Significantly more cases had no $(7.7 \%)$ or primary education $(32.8 \%)$ than controls $(3.7 \%$ and $19.7 \%$ respectively, $\mathrm{p}<0.001$ ). In contrast $14.2 \%$ of cases and $28.8 \%$ of controls had a higher education $(\mathrm{p}<0.001)$.

Table 1 Characteristics of matched cases (hospitalized inpatients) and controls (outpatients) with confirmed pandemic influenza A (H1N1) 2009

\begin{tabular}{|c|c|c|c|}
\hline Characteristic & & $\begin{array}{l}\text { Cases } \\
\text { N (699) }\end{array}$ & $\begin{array}{l}\text { Controls } \\
\text { N (699) }\end{array}$ \\
\hline Mean age $(*)$ & & 37.82 & 33.69 \\
\hline \multirow[t]{2}{*}{ Sex } & Male $\left(^{*}\right)$ & $342(49.1)$ & $301(43.1)$ \\
\hline & Female $\left(^{*}\right)$ & $356(50.9)$ & $397(56.9)$ \\
\hline \multirow[t]{5}{*}{ Ethnicity } & White $\left(^{* *}\right)$ & $588(87.1)$ & $634(94.1)$ \\
\hline & Roma $\left({ }^{* *}\right)$ & $15(2.2)$ & $2(0.3)$ \\
\hline & Amerindian $(* *)$ & $46(6.8)$ & $16(2.4)$ \\
\hline & $\begin{array}{l}\text { Arab or North } \\
\text { African }\left(^{*}\right)\end{array}$ & $17(2.5)$ & $6(0.9)$ \\
\hline & Other & $10(1.5)$ & $18(2.7)$ \\
\hline \multirow[t]{4}{*}{ Educational level } & $\begin{array}{l}\text { No formal } \\
\text { education }(* *)\end{array}$ & $50(7.7)$ & $24(3.7)$ \\
\hline & Primary $(* *)$ & $213(32.8)$ & $128(19.7)$ \\
\hline & Secondary & $295(45.4)$ & $311(47.8)$ \\
\hline & Higher $(* *)$ & $92(14.2)$ & $187(28.8)$ \\
\hline \multirow[t]{3}{*}{ Overcrowding } & $>=29 \mathrm{~m}^{2} / \mathrm{p}$ & $234(45.7)$ & $252(49.2)$ \\
\hline & $28-15 \mathrm{~m}^{2} / \mathrm{p}$ & $237(46.3)$ & $240(47.1)$ \\
\hline & $<=14 \mathrm{~m}^{2} / \mathrm{p}\left({ }^{* *}\right)$ & $41(8)$ & $20(3.7)$ \\
\hline \multirow{4}{*}{$\begin{array}{l}\text { Unfavourable medical } \\
\text { factors }\end{array}$} & $0\left({ }^{* *}\right)$ & 242 (34.6) & $382(54.6)$ \\
\hline & 1 & $230(32.9)$ & $238(34)$ \\
\hline & $2(* *)$ & $122(17.5)$ & $58(8.3)$ \\
\hline & $>2(* *)$ & $105(15)$ & $21(3)$ \\
\hline \multirow{2}{*}{$\begin{array}{l}\text { Prior preventive } \\
\text { information }\end{array}$} & Yes $\left(^{* *}\right)$ & $577(82.5)$ & 639 (91.4) \\
\hline & No $\left({ }^{* *}\right)$ & $122(17.5)$ & $60(8.6)$ \\
\hline \multirow{2}{*}{$\begin{array}{l}\text { Prior pandemic } \\
\text { vaccination }\end{array}$} & No & 691 (99) & 697 (99.9) \\
\hline & Yes & $7(1)$ & $1(0.1)$ \\
\hline \multirow{2}{*}{$\begin{array}{l}\text { Previous outpatient } \\
\text { care }\end{array}$} & No $(* *)$ & $357(51.1)$ & $557(79.7)$ \\
\hline & Yes $\left({ }^{* *}\right)$ & $342(48.9)$ & $142(20.3)$ \\
\hline \multirow{2}{*}{$\begin{array}{l}\text { Previous emergency } \\
\text { care }\end{array}$} & No $(* *)$ & 488 (69.8) & $603(86.3)$ \\
\hline & Yes $\left({ }^{* *}\right)$ & $211(30.2)$ & $96(13.7)$ \\
\hline
\end{tabular}

(*) $\mathrm{P}<0.05,(* *) \mathrm{p}<0.01$. 
Significantly more cases (8.0\%) than controls $(3.7 \%)$ had a living space of less than $14 \mathrm{~m}^{2}$. Significantly fewer cases $(34.6 \%)$ than controls $(54.6 \%)$ had no risk factor or comorbidity ( $p<0.001)$. In contrast, more cases than controls had $\geq 2$ risk factor $(\mathrm{p}<0.001)$. Likewise, $17.5 \%$ of cases but only $8.6 \%$ of controls had received no information about preventing the transmission of influenza. Visits to primary care or hospital emergency services in the days before infection were significantly higher in cases than in controls ( $\mathrm{p}<0.001$ ).

Table 2 shows the results of the bivariate and multivariate analyses. No significant differences were found between sexes in the proportion of hospitalized cases. Hospitalization was associated with non-Caucasian ethnicity (Roma, Amerindian, Arab or North African) (OR 2.18, CI (95\%): $1.17-4.08)$, and personal space $<14 \mathrm{~m}^{2}$ per person (OR: 2.84, 95\% CI $1.20-6.72$ ). Patients with secondary or higher education had a lower probability of hospitalization than patients without formal education or with only primary education (OR: 0.56 ; 95\% CI: 0.36-0.87).

Receiving information on preventive measures was a protective factor against hospitalization. The probability of hospitalization was higher in patients who had received no information (OR: 2.69 95\% CI: 1.50 - 4.83).

Hospitalization due to influenza increased according to the number of risk factors and comorbidities (OR: 1.60, 95\% CI: $1.07-2.40$ for one, OR: 2. 94, 95\% CI $1.61-5.36$ for two and OR: $18.51,95 \%$ CI $6.08-56.41$ for $\geq 3$ risk factors or comorbidities).

During the pandemic period, hospitalized cases made more visits to primary care centres (OR 3.46, 95\% CI $2.22-5.39$ ) and outpatient emergency services (OR $2.68,95 \%$ CI 1.66 - 4.32) compared with controls.

\section{Discussion}

The relationship between specific unfavourable medical conditions and the severity of influenza infection has been widely studied with respect to the 2009 pandemic $[23,31,32]$. The number of comorbidities, which increases with age, was an important factor in this respect, as shown by other studies made of the pandemic [23,31]. The World Health Organization working group on risk factors associated with severe A (H1N1) 2009 virus infection found that the proportion of cases with chronic disease increased significantly in tandem with disease severity. The risk factors were similar to those of seasonal influenza, except for differences related to age [32].

Spanish studies have found a greater frequency of comorbidity in people aged $\geq 65$ years, which was associated with hospitalization [20,23]. Our results also show that the probability of hospitalization increased in tandem with the number of comorbidities, and that the influence of these predisposing factors was independent of other factors analysed.
Various studies have shown a relationship between the health status and social inequalities [2-7] that goes beyond access to health services to include other factors such as income, housing, education, ethnicity, etc., which may determine the gradient of health between social groups $[33,34]$. The present study assessed some of these factors, including the educational level, ethnicity, overcrowding in living conditions, and access to preventive information and primary care services.

Given that influenza is transmitted aerially, overcrowding or workplace characteristics [35] or the use of public transport [36] can also predispose to a greater risk of exposure. Like other studies, we found a significant association between disease severity and a greater degree of overcrowding, even with a threshold for overcrowding that may be considered moderate [37]. Although we did not find that this effect was modified by other factors such as ethnicity or educational level, we suggest that this association may be due to the relationship between overcrowding and income levels, which influence disease severity.

Spanish [38] and other [39,40] descriptive studies show differences in the use of health services and in hospitalization due to the complications of influenza during the 2009 pandemic in immigrants and ethnic minorities, on the one hand, and indigenous people on the other hand. We found that non-Caucasian ethnicity was associated with greater disease severity. Although the small number of non-Caucasians included in the study did not permit analysis by ethnic groups in the multivariate models. However, the descriptive statistics suggest that greater disease severity occurred especially in Roma and North African or South American immigrants.

Studies have shown that preventive measures, including influenza vaccination, reduce mortality due to pneumonia and influenza in socially-deprived areas [16]. The fact that more-highly educated people have a higher socioeconomic level, have more information on avoiding risks and more-easily access health services [41] for general health care and for early care of other underlying conditions that may worsen the severity of influenza, may explain the association we found between lower educational levels and disease severity.

We found that hospitalized patients more-frequently attended primary care clinics and emergency units in the days before the onset of influenza. This may be related to the previous health status of hospitalized patients. Because the Spanish health system has universal coverage, it seems unlikely that inequalities in access to health care, as suggested by other authors [42], could explain our results. Although the study design did not permit assessment of the degree of compliance with preventive measures, people who had received preventive information had fewer hospitalizations. 
Table 2 Comparison of cases (hospitalized patients) and controls (outpatients) with confirmed pandemic influenza A (H1N1) 2009

\begin{tabular}{|c|c|c|c|c|c|}
\hline Independent variables & & $\begin{array}{l}\text { Cases } \\
(\mathrm{N}=699)\end{array}$ & $\begin{array}{l}\text { Controls } \\
(\mathrm{N}=699)\end{array}$ & Crude OR (95\%) & Adjusted OR (95\%) \\
\hline \multirow[t]{2}{*}{ Sex } & Male & 342 & 301 & 1 & 1 \\
\hline & Female & 356 & 397 & $0.79(0.61-1.01)$ & $0.72(0.51-1.01)$ \\
\hline \multirow[t]{2}{*}{ Ethnicity } & White & 588 & 634 & 1 & 1 \\
\hline & Other & 88 & 42 & $2.39^{* *}(1.45-3.98)$ & $2.18^{* *}(1.17-4.08)$ \\
\hline \multirow[t]{2}{*}{ Educational level } & No/primary education & 263 & 152 & 1 & 1 \\
\hline & Secondary or higher & 387 & 498 & $0.38^{* *}(0.27-0.53)$ & $0.56^{* *}(0.36-0.87)$ \\
\hline \multirow[t]{3}{*}{ Overcrowding } & $>=29 \mathrm{~m}^{2}$ & 234 & 252 & 1 & 1 \\
\hline & $28-15 m^{2}$ & 237 & 240 & $1.07(0.78-1.49)$ & $1.09(0.76-1.57)$ \\
\hline & $<=14 \mathrm{~m}^{2}$ & 41 & 20 & $3^{*}(1.04-10.55)$ & $2.84^{*}(1.20-6.72)$ \\
\hline \multirow[t]{4}{*}{ Unfavourable medical factors } & 0 & 242 & 382 & 1 & 1 \\
\hline & 1 & 230 & 238 & $1.78^{* *}(1.25-2.53)$ & $1.60^{*}(1.07-2.40)$ \\
\hline & 2 & 122 & 58 & $3.99 * *(1.99-8.03)$ & $2.94^{* *}(1.61-5.36)$ \\
\hline & $>2$ & 105 & 21 & $38^{* *}(6.42-153.99)$ & $18.51^{* *}(6.08-56.41)$ \\
\hline \multirow[t]{2}{*}{ Previous preventive information } & Yes & 577 & 639 & 1 & 1 \\
\hline & No & 122 & 60 & $2.38^{* *}(1.56-3.66)$ & $2.69^{* *}(1.50-4.83)$ \\
\hline \multirow[t]{2}{*}{ Prior pandemic vaccination } & No & 691 & 697 & 1 & 1 \\
\hline & Yes & 7 & 1 & - & - \\
\hline \multirow[t]{2}{*}{ Previous outpatient care } & No & 357 & 557 & 1 & 1 \\
\hline & Yes & 342 & 142 & $4.57^{* *}(3.23-6.51)$ & $3.46^{* *}(2.22-5.39)$ \\
\hline \multirow[t]{2}{*}{ Previous emergency care } & No & 488 & 603 & 1 & 1 \\
\hline & Yes & 211 & 96 & $3.02^{* *}(2.10-4.35)$ & $2.68^{* *}(1.66-4.32)$ \\
\hline
\end{tabular}

Results of the bivariate analysis (crude OR) and conditional logistic regression (adjusted OR).

$(*) P<0.05,(* *) p<0.01$.

This study has some limitations. The control group was not representative of the whole population infected, as it was selected from patients who visited their family physician for treatment for influenza. However, we believe this does not invalidate the results with respect to the study objectives. Both cases and controls were asked if they had received previous preventive information: however, we do not know to what degree this information was followed. However, given that we found significant differences in the results between patients who did and did not receive preventive information, the differences may have been even greater in those patients who did follow the advice given. Likewise, we were unable to evaluate the effect of previous vaccination or early antiviral treatment due to the small number of study patients who received these measures within the time required to evaluate them, even though vaccination was included in the adjusted analysis. The large number of missing values found for the variable overcrowding was assessed by comparing the characteristics of pairs with and without information on this variable. We found no significant differences, suggesting that the missing values do not compromise the validity of the results. However, other social and environmental factors of interest may not have been collected and analysed and therefore some residual confounding cannot be ruled out.

Efforts to reduce the impact of social inequality on the effects of communicable disease epidemics, such as influenza, must be undertaken not only by front-line health care services but also by preventive services and nonhealth care agents. Health interventions can reduce, but not eliminate health inequalities, as other sociodemographic determinants are not susceptible to these interventions and require a multidisciplinary approach. The adoption of plans and interventions that address the differential demographic impact of influenza may help to partially prevent the consequence of social inequalities on disease outcomes $[1,11]$. However, awareness of the risk of the "inverse care law" [43], that is, increased inequality due to the higher social classes having better access to preventive interventions should also be heightened.

\section{Conclusions}

The main conclusions of this study are that, in addition to individual factors such as pre-existing unfavourable medical conditions, other social factors, such as non- 
Caucasian ethnicity, the lack of information on preventive measures, overcrowding, and a primary education or less, increased the risk of hospitalization due to confirmed influenza.

\section{Competing interests}

All the authors declare that no financial competing interest exists with any companies or organizations whose products or services may be discussed in this article and that there are no non-financial competing interests (political, personal, religious, academic, ideological, intellectual, commercial or any other) in relation to the manuscript.

\section{Authors' contributions}

JMM directed the study and drew up the manuscript, together with $\mathrm{ZH}$; $\mathrm{AF}$ and JMM carried out the statistical analysis; AD, OG and JA supervised the statistical analysis and the drawing up of the manuscript. JMM, AD and AF had full access to all the study data and take responsibility for the data and the accuracy of the analysis; NS and $M B$, supervised the administration of the data base; JA, RC, JC, AC, MDR, PG, FGC, VM, TP, JMQ and ST contributed to the design and supervision of the study and critical analysis of the article. The members of the CIBERESP Cases and Controls in Pandemic Influenza Working Group designed the case-control study on which this article is based. The other members of the CIBERESP Cases and Controls in Pandemic Influenza Working Group contributed to patient recruitment, data collection and interpreting the study results and have given final approval of the version to be published.

\section{Acknowledgements}

We thank the physicians of the Sentinel Network of the participating Spanish regions and the study interviewers for their help and collaboration.

\section{Financial support}

This study was supported by the Ministerio de Ciencia e Innovación, Instituto de Salud Carlos III, Programa de Investigación sobre Gripe A/H1N1 (Grant GR09/0030), and Agency for the Management of Grants for University Research (AGAUR Grant number 2009/SGR 42).

The other members of the CIBERESP Cases and Controls in Pandemic Influenza Working Group are: Andalusia: E Azor, J Carrillo, R Moyano, J A Navarro, M Vázquez, F Zafra (Sentinel physicians), M A Bueno, M L Gómez, M Mariscal, B Martínez, J P Quesada, M Sillero (Complejo Hospitalario de Jaén), M Carnero, J Fernández-Crehuet, J del Diego Salas (Hospital Virgen de la Victoria), V Fuentes (Hospital Costa del Sol), V Gallardo, E Pérez (Servicio de Epidemiología), R López (Hospital Infanta Elena de Huelva), J R Maldonado (Hospital de Torrecárdenas), A Morillo (Hospital Virgen del Rocío), J M Navarro, M Pérez (Laboratorio de Referencia de Gripe), S Oña (Hospital Carlos Haya), M J Pérez (Hospital Virgen de Valme), M C Ubago (Hospital Virgen de las Nieves), M Zarzuela (Hospital Puerta del Mar). Valencia Community: J Blanquer (Hospital Clínico de Valencia), M Morales (Hospital Doctor Peset), Red Centinela Sanitaria de la Comunidad Valenciana. Castile and Leon: D Carriedo, F Díez, I Fernández, S Fernandez, M P Sanz (Complejo Asistencia Universitario de León), J J Castrodeza, A Pérez (Dirección General de Salud Pública e Investigación, Desarrollo e Innovación), R Ortiz de Lejarazu (Centro Nacional de Gripe de Valladolid), J Ortiz (Hospital de El Bierzo), A Pueyo, J L Viejo (Complejo Asistencial de Burgos), P Redondo (Servicio Territorial de Sanidad y Bienestar Social de León), A Molina (Instituto de Biomedicina, Universidad de León) Catalonia: A Agustí, ATorres, ATrilla, A Vilella (Hospital Clínic); F Barbé (Hospital Arnau de Vilanova); L Blanch, G Navarro (Hospital de Sabadell); X Bonfill, J López-Contreras, V Pomar, M T Puig (Hospital de Sant Pau); E Borràs, A Martínez, N Torner (Dirección General de Salud Pública); C Bravo, F Moraga (Hospital Vall d'Hebrón); F Calafell (Universitat Pompeu Fabra);_J Caylà, CTortajada (Agencia de Salud Publica de Barcelona); I Garcia, J Ruiz (Hospital Germans Trias i Pujol); J J García (Hospital Sant Joan de Deu); J Gea, J P Horcajada (Universitat Pompeu Fabra- CIBER Enfermedades Respiratorias); N Hayes (Hospital Clínic_CRESIB); A Rosell (Hospital de Bellvitge); M Saez (Universitat de Girona). Madrid: C Álvarez, M Enríquez, F Pozo (Hospital 12 de Octubre), F Baquero, JC Galán, A Robustillo, M Valdeón (Hospital Universitario Ramón y Cajal), E Córdoba, F Dominguez, J García, R Génova, E Gil, S Jiménez, M A Lopaz, J López, F Martín, M L Martínez, M Ordobás, E Rodriguez, S Sánchez, C Valdés (Área de Epidemiología de la Comunidad de Madrid), J R Paño, M Romero (Hospital Universitario La Paz).
Navarre: A Martinez, L Martínez (Instituto de Salud Pública), M Ruiz, P Fanlo, F Gil, V Martínez-Artola (Complejo Hospitalario de Navarra), ME Ursua, M Sota, MT Virto, J Gamboa, F Pérez-Afonso (Sentinel physicians). The Basque Country: U Aguirre, A Caspelastegui, PP España, S García, (Hospital Galdakao), JM Antoñana, I Astigarraga, J I Pijoan, I Pocheville, M Santiago, J I Villate (Hospital de Cruces), J Arístegui, A Escobar, M I Garrote (Hospital Basurto), A Bilbao, C Garaizar (Fundación Vasca de Innovación e Investigación Sanitarias), G Cilla, J Korta, E Pérez Trallero, C Sarasqueta (Hospital Donostia), F Aizpuru, C Salado, J L Lobo (Hospital Txagorritxu), J Alustizac (Hospital Mendaro).

\section{Author details}

${ }^{1}$ Servicio de Vigilancia epidemiológica de Andalucia, Sevilla, Spain. ${ }^{2}$ Institut Municipal de Investigació Mèdica, Barcelona, Spain. ${ }^{3}$ CIBER Epidemiología y Salud Pública, Barcelona, Spain. ${ }^{4}$ Programa de Epidemiología Aplicada de Campo, ISCIII, Madrid, Spain. ${ }^{5}$ Área de Epidemiología, Comunidad de Madrid, Madrid, Spain. ${ }^{6}$ Instituto de Salud Pública de Navarra, Pamplona, Spain. ${ }^{7}$ Hospital Universitario Ramón y Cajal, Madrid, Spain. ${ }^{8} \mathrm{CIBER}$ Enfermedades Respiratorias_Instituto de Investigación Hospital 12 de Octubre, Madrid, Spain. ${ }^{9}$ Universidad de Jaén, Jaén, Spain. ${ }^{10}$ Departament de Salut, Generalitat of Catalonia, Barcelona, Spain. ${ }^{11}$ Centro Superior de Investigación en Salud Pública, Universitat de València, València, Spain. ${ }^{12}$ Instituto de Biomedicina, Universidad de Leon, Leon, Spain. ${ }^{13}$ Red Española de Investigación en Patología Infecciosa, Madrid, Spain. ${ }^{14}$ Unidad de Investigación, Hospital Galdakao-Usansolo, San Sebastian, Spain. ${ }^{15}$ Dirección General de Salud Pública e Investigación, Desarrollo e Innovación, Junta de Castilla y León, Valladolid, Spain. ${ }^{16}$ Departament de Salut Pública, Universitat de Barcelona, Barcelona, Spain. ${ }^{17}$ So de Epidemiología. Consejería de Salud. Andalucía, Avda. de la Innovación s/n, 41080, Sevilla, Spain.

Received: 14 November 2012 Accepted: 29 January 2013

Published: 7 February 2013

\section{References}

1. Semenza JC, Giesecke J: Intervening to reduce inequalities in infections in Europe. Am J Public Health 2008, 98:787-92.

2. Wilkinson RG, Pickett KE: Income inequality and population health: a review and explanation of the evidence. Soc Sci Med 2006, 62:1768-84.

3. Mackenbach JP, Kunst AE, Cavelaars AE, Groenhof F, Geurts JJ: Socioeconomic inequalities in morbidity and mortality in western Europe. The EU Working Group on Socioeconomic Inequalities in Health. Lancet 1997, 349:1655-59.

4. Marmot MG, Kogevinas M, Elston MA: Social/economic status and disease. Ann Rev of Public Health 1987, 8:111-35.

5. Whitehead M, Burstrom B, Diderichsen F: Social policies and the pathways to inequalities in health: a comparative analysis of lone mothers in Britain and Sweden. Soc Sci Med 2000, 50:255-70.

6. Regidor E, Martinez D, Astasio P, Ortega P, Calle ME, Dominguez V: Trends of socioeconomic inequalities and socioeconomic inequalities in selfperceived health in Spain. Gac Sanit 2006, 20:178-82.

7. Marmot M, Wilkinson RG: Psychosocial and material pathways in the relation between income and health: a response to Lynch et al. BMJ 2001, 322:1233-6h.

8. Pradas Velasco R, Villar FA, Puy Martínez-Zárate M: Use of European Quality of Life-5 Dimensions (EQ-5D) questionnaire to value the health related quality of life variation because of influenza. Gac Sanit 2009, 23:104-8.

9. Ministerio de Sanidad y Política Social de España (MSPS): Hacia la equidad en salud: monitorización de los determinantes sociales de la salud y reducción de las desigualdades en salud. 2010, Disponible en: http://www.msps.es/profesionales/saludPublica/prevPromocion/promocion/ desigualdadSalud/PresidenciaUE_2010/conferenciaExpertos/docs/ haciaLaEquidadEnSalud.pdf

10. Regidor E, De Mateo S, Calle ME, Domínguez V: Educational level and mortality from infectious diseases. J Epidemiol Community Health 2002, 56:682-3.

11. Semenza JC, Suk JE, Tsolova S: Social determinants of infectious diseases: a public health priority. Euro Surveill 2010, 15:2-4

12. Oxford JS, Sefton A, Jackson R, Innes W, Daniels RS, Johnson NP: World War I may have allowed the emergence of "Spanish" influenza. Lancet Infect Dis 2002, 2:111-4.

13. Marmot MG, et al: Fair society, healthy lives: the marmot review. London:; 2010. Available online: http://www.marmotreview.org/. 
14. Agüero F, Adell MN, Pérez Giménez A, et al: Adoption of preventive measures during and after the 2009 influenza $A$ (H1N1) virus pandemic peak in Spain. Prev Med 2011, 12. Epub ahead of print.

15. Yamada T: Poverty, wealth, and access to pandemic influenza vaccines. $N$ Engl J Med 2009, 361:1129-31.

16. Ferreira Antunes JL, Waldman EA, Borrell C, Paiva TM: Effectiveness of influenza vaccination and its impact on health inequalities. Int $J$ Epidemiol 2007, 36:1319-1326.

17. Santa-Olalla P, Cortes-García M, Vicente-Herrero M, Surveillance Group for New Influenza $\mathrm{A}(\mathrm{H} 1 \mathrm{~N} 1)$ Virus Investigation and Control Team in Spain, et al: Risk factors for disease severity among hospitalised patients with 2009 pandemic influenza A (H1N1) in Spain, April - December 2009. Euro Surveill 2010, 15(38):pii=19667. Available online: http://www.eurosurveillance. org/NiewArticle.aspx?Articleld=19667.

18. Centers for Disease Control and Prevention (CDC): Patients hospitalized with 2009 pandemic influenza A (H1N1) - New York City, May 2009. MMWR 2010, 58:1436-40.

19. Nickel KB, Marsden-Haug NL, Kathryn $H$, et al: Age as an independent risk factor for Intensive Care Unit admission or death due to 2009 pandemic influenza A(H1N1) virus infection. Public Health Reports 2011, 126:349-53.

20. Mayoral Cortés JM, Puell Gómez L, Pérez Morilla E, et al: Behaviour of the pandemic H1N1 influenza virus in Andalusia, Spain, at the onset of the 2009-10 season. Euro Surveill 2009, 14(49):pii=19433. Available online: http://www.eurosurveillance.org/ViewArticle.aspx?Articleld=19433.

21. Simón Méndez L, de Mateo OS, Larrauri Cámara A, et al: Transmisibilidad y gravedad de la pandemia de gripe $A(H 1 N 1) 2009$ en España. Gac Sanit 2011, 25:296-302

22. Echevarría-Zuna E, Mejía-Aranguré JM, Mar-Obeso AJ, et al: Infection and death from influenza $A(\mathrm{H} 1 \mathrm{~N} 1)$ virus in Mexico: a retrospective analysis. Lancet 2009, 374:2072-9.

23. Santa-Olalla P, Cortes García M, Limia Sánchez A, et al: Casos de infección por gripe pandémica (H1N1) 2009 hospitalizados en cuidados intensivos en España: factores asociados a riesgo de muerte, abril 2009-enero 2010. Rev Esp Salud Publica 2010, 84:547-567.

24. Domínguez A, Alonso J, Astray J, Grupo de Trabajo del Proyecto CIBERESP de Casos y Controles sobre la Gripe Pandémica, et al: Risk factors of influenza (H1N1) 2009 hospitalization and effectiveness of pharmaceutical and nonpharmaceutical interventions in its prevention: a case-control study. Rev Esp Salud Publica 2011, 85:3-15.

25. Garin O, Galante M, García-Altés A, et al: Use of services and costs in patients with Influenza (H1N1) 2009 in Spain: background and research protocol. Rev Esp Salud Pública 2011, 85:19-31.

26. Brouwers L, Cakici B, Camitz M, Tegnell A, Boman M: Economic consequences to society of pandemic H1N1 influenza 2009 - preliminary results for Sweden. Euro Surveill 2009, 14(37):pii=19333. Available online: http://www.eurosurveillance.org/ViewArticle.aspx?Articleld=19333.

27. Bennett KJ, et al: Rural-urban differences in the location of influenza vaccine administration. Vaccine 2011, 29:5970-5977.

28. Yousey-Hindes KM, James L: Hadler neighborhood socioeconomic status and influenza hospitalizations among children: New haven county, Connecticut, 2003-2010. Am J Public Health 2011, 101:1785-1789.

29. Commission of the European Communities: Together for health: a strategic approach for the EU 2008-2013. Brussels:; 2007. http://ec.europa.eu/health/ ph_overview/Documents/strategy_wp_en.pdf.

30. Schlesselman JJ: Case-control studies. Design, conduct, analysis. New York: Oxford University Press; 1982:144-70.

31. Louie JK, Acosta M, Winter K, et al: Factors associated with death or hospitalization due to pandemic 2009 influenza $\mathrm{A}(\mathrm{H} 1 \mathrm{~N} 1)$ infection in California. JAMA 2009, 302:1896-902.

32. Van Kerkhove MD, Vandemaele KA, Shinde $\mathrm{V}$, on behalf of the $\mathrm{WHO}$ Working Group for Risk Factors for Severe H1N1 Infection, et al: Risk factors for severe outcomes following 2009 Influenza A (H1N1) Infection: a global pooled analysis. PLoS Med, 8(7):e1001053. doi:10.1371/journal. pmed.1001053.

33. Dahlgren, Whitehead: "Policies and strategies to promote social equity in health. Background document to WHO - Strategy paper for Europe". Arbetsrapport. Stockholm, Sweden: Institute for Futures Studies; 2007:14. ISBN 978-91-85619-18-4.

34. Kramers PGN: The ECHI project. Health indicators for the European community. Eur J Public Health 2003, 13(suppl 3):101-106.
35. Williams CJ, Schweiger B, Diner G, et al: Seasonal influenza risk in hospital healthcare workers is more strongly associated with household than occupational exposures: results from a prospective cohort study in Berlin, Germany, 2006/07. BMC Infect Dis 2010, 10:8. http://www. biomedcentral.com/1471-2334/10/8

36. Troko J, Myles P, Gibson J, et al: Is public transport a risk factor for acute respiratory infection? BMC Infectious Diseases 2011, 11:16. http://www. biomedcentral.com/1471-2334/11/16.

37. Maldonado JL, Cortés Alcalá L: Características del parque de viviendas de la Comunidad de Madrid según el Censo de 2001. Consejería de Economía e Innovación Tecnológica. Instituto de Estadística de la Comunidad de Madrid: Instituto de Estadística de la Comunidad de Madrid; :1435-2005. DL:M. ISBN 84-451-2714-4

38. Esteban-Vasallo MD, Domínguez-Berjón MF, Aerny-Perreten N, et al: Pandemic influenza A (H1N1) 2009 in Madrid, Spain: incidence and characteristics in immigrant and native population. Eur J Public Health. doi:10.1093/eurpub/ckr171. ckr171 first published online December 8, 2011.

39. Truman $B$ I, Tinker $T$, Vaughan $E$, et al: Pandemic influenza preparedness and response among immigrants and refugees. Am J Public Health 2009, 99(Suppl 2):S278-286.

40. Centers for Disease Control and Prevention. (CDC): Deaths related to 2009 pandemic influenza A (H1N1) among American Indian/Alaska Natives 12 states. MMWR 2009, 58:1341-4.

41. Benach J, Amable M: Las clases sociales y la pobreza. Gac Sanit 2004 18(Supl 1):16-23.

42. Márquez Calderón S, Villegas Portero R, Aguado Romeo MJ: La utilización de los servicios sanitarios en Andalucía: ¿perpetuación o corrección de las desigualdades? Primer Informe sobre Desigualdades y Salud en Andalucía. Edita: Asociación para la Defensa de la Sanidad Pública de Andalucía (ADSPA); 2008:145-165.

43. O'Malley AS, Forrest CB: Immunization disparities in older Americans: determinants and future research needs. Am J Prev Med 2006, 31:150-8.

\section{doi:10.1186/1471-2458-13-118}

Cite this article as: Mayoral et al: Social factors related to the clinical severity of influenza cases in Spain during the A (H1N1) 2009 virus pandemic. BMC Public Health 2013 13:118.

\section{Submit your next manuscript to BioMed Central and take full advantage of:}

- Convenient online submission

- Thorough peer review

- No space constraints or color figure charges

- Immediate publication on acceptance

- Inclusion in PubMed, CAS, Scopus and Google Scholar

- Research which is freely available for redistribution 